\title{
Brazilian women's transition to new relationships after ending a violent one: a case study
}

\author{
Priscila de Oliveira Parada* \\ Sheila Giardini Murta
}

\author{
University of Brasilia, Graduate Program in Clinical Psychology and Culture. Brasília, Brazil
}

\begin{abstract}
This study investigated characteristics of the transition to new relationships after the end of a violent one through case studies. Two young white Brazilian women who had experienced violent first relationships underwent a narrative interview and filled out the Experiences in Close Relationships Inventory. One of them had moved to a healthy relationship and the second one to another violent relationship. Awareness of violence and the adoption of strategies that enlarged models, world views, social circles, support and self care had not been enough to avoid the entrance in a new violent relationship. The development of the ability to access and validate one's own feelings and wills, resulting in greater assertiveness, favored the transition to a healthy relationship. The approach to secure attachment style accompanied such changes. We discuss the implications to professional practice and preventive initiatives, as well as directions for future research.
\end{abstract}

Keywords: intimate partner violence, violence against women, prevention, attachment.

It is estimated that half the female homicides in the world are committed by a partner or boyfriend. In Brazil, violence against women committed by intimate partners is one of the most serious health problems for women. Repeated violence, either physical or sexual, is among the primary causes of female mortality, especially among black and less-educated women (Barufaldi et al., 2017). Furthermore, evidence points to an increase in domestic violence in Brazil in the last decade, placing women, whether adult or adolescent, at higher risk (Rodrigues et al., 2017). The impacts of violence against women are devastating and reflect on occupational (absenteeism, tardiness, and lowered productivity), social (increased use of health and police services and banalization of violence) and health aspects (lower quality of life, injuries, suicide, death by homicide) (Barufaldi et al., 2017).

Thus, the implementation of preventive and protective measures at the macro, meso, and micro levels is urgent. For women already victimized by their intimate partners, ending the abusive relationship is a way to prevent the aggravation of damage and gain protection in the face of violence. Nevertheless, ending a violent relationship is a complex phenomenon, with gains and losses (Estrellado \& Loh, 2019), and it is not synonymous with overcoming violence. Firstly, interrupting the aggression does not coincide, necessarily, with the end of the relationship. Actually, the latter frequently results in an aggravation of violence, at least in the short term. Secondly, it is not uncommon among people who

* Corresponding address: parada.priscila@gmail.com experienced violent relationships to repeat that pattern in the future (Martsof, Draucker, Stephenson, Cook, \& Heckman, 2012).

The study of the outcomes of violence after ending a relationship is still nascent and has little to say about this period and its relevance in overcoming violence from an intimate partner. Bell, Goodman, and Dutton (2007) did a one-year longitudinal study in which they analyzed relationship status, victimization, and well-being every three months. The results indicate that the women who spent the entire period out of the relationship had greater well-being and lower victimization. Next came the women who were in a relationship for the whole period, without break-ups, for whom well-being was slightly lower and victimization higher compared to the previous group. They observed the worst results in the group of women who alternately restarted and ended their relationship over the year.

Some studies that focused on the process of ending violent relationships paid attention to the circumstances of the post-breakup period, exploring aspects such as the obstacles and difficulties experienced and strategies adopted to remain broken-up (Anderson, 2003; Burke, Gielen, McDonnel, O'Campo, Maman, 2001; Murta, Ramos, Cangussu, Tavares, \& Costa, 2014). These obstacles and difficulties were how to cope with still being in love (if the victim still was) and the need to remain in contact for the children's sake (Burke et al., 2001). The strategies identified to cope with such difficulties were: to remain resolute about the decision to end the abuse and to keep a safe distance from the ex-partner (Burke et al., 2001); self-awareness of the risk of relapse; 
management of rapprochement triggers by attending to previously neglected personal needs; analyzing gains and losses; improving self-esteem; dedicating oneself to new projects and seeking social support (Murta et al., 2014); attending support groups; seeking new non-violent relationships; and maintaining high self-esteem and happiness (Anderson, 2003).

Similarly, the transition to new relationships after the ending of violent ones is not a well-known subject and is rarely investigated (Carbonne-Lopez, Rennison, \& MacMillan, 2011; Greenman \& Matsuda, 2016; Martsolf et al., 2012). There is evidence that, although the transition to non-violent relationships is possible, entering a new violent relationship is not an exception in the outcomes for people who have already been in one. Martsolf et al. (2012), based on the data from 88 participants, proposed a classification of violent relationships that includes one single violent relationship or more than one. In the latter case, the authors found two possibilities: similar aggression severity between the different relationships or an increase in severity from the first to the next. Carbonne-Lopez et al. (2011) used data from the National Violence Against Women Survey from the United States and found that women who experienced a first violent relationship had a greater chance of moving to no relationship at all followed by a high chance of entering relationships with conflict and aggression coming from the partner. Least likely was moving to a non-violent relationship. The authors found victimization by parents or caretakers in childhood to correlate with a greater chance of being in multiple violent relationships. Greenman and Matsuda (2016), in turn, found correlation between the perpetration of relationship violence at the beginning of adult life and in future, stable intimate relationships (e.g.: marriage, long-term relationship). They also found supportive relationships with family members and peers to be protective and to decrease the trend of continued violence.

Thus, a chain of several violent relationships is a known possibility, though not a predetermined outcome, as the aforementioned few available studies have shown that some people move on to non-violent relationships. Moreover, overcoming violence in romantic relationships can be envisaged either within relationships themselves by ending the use of violence or through the ending of violent relationships and beginning of new healthy ones, being this last process the main interest of this study

Ending, thus, is a necessary process that precedes transition. We adopted the framework from the Transtheoretical Model of Change (Prochaska, DiClemente, \& Norcross, 1992) as it has been applied in previous studies (Anderson, 2003; Burke et al., 2001; Keeling, Smith, \& Fisher, 2016). According to this model, five stages compose the process of change: pre-contemplation, contemplation, preparation, action and maintenance. Pre-contemplation consists of the lack of or precarious awareness about the problem (e.g. tries to minimize the harm of violence, or attributes guilt to oneself for the other person's aggression). Contemplation happens when the person is conscious about the problem and the need to change, but still does not act to do so (e.g. clearly recognizes violence in the relationship). Preparation consists of distinct trials to change the situation, although they are not consistent enough to reach the criterium of action (e.g. talks to the partner about changes that need to happen, retakes friendships to have more support to face the break-up, breaks-up and makes-up within a few days, seeks for self care activities in order to fortify oneself). Action takes place when consistent measures are taken to solve the problem achieving satisfactory criteria (e.g. ends the relationship and remains this way for at least two months). Maintenance demands the change to persevere throughout time (e.g. woman does not resume the relationship anymore) (Brown, 1997).

The transition to a new healthy or violent romantic relationship may be impacted by emotional and affective aspects. Considering this, our study adopted the attachment theory for understanding this process. Attachment theory, proposed by Bowlby (1998), indicates the receptiveness and the accessibility of the objects of attachment as fundamental factors in the development of safe, affective connections. The author studied how the experiences of separation, loss, and the lack of receptivity of caregivers in childhood promoted deficiencies in adaptation and autonomy, trusting other people and oneself, and receiving and offering help. On the other hand, children whose parents provided comfort and protection, especially during situations that caused insecurity and/or fear, reached greater degrees of autonomy and self-confidence. This is demonstrated in a positive way in several fields of development, particularly interpersonal relationships and the ability to face adversity and cope with challenges throughout life, all strongly present in the establishment of intimate relationships (Bartholomew, 1997).

By the end of the 1980s, the concept of attachment began to be applied to adult life (George, Kaplan, \& Main, 1985; Hazan \& Shaver, 1987; Johnson, 1986). Some of its principles comprehend dependence not as something undesirable, but as a characteristic intrinsic to human beings which, when consistent in secure dependence, allows autonomy and connections (Johnson, 2012). Thus, attachment offers a secure base from which it is possible to explore the environment and adapt while having support for the hardships resulting from this process. This way, when faced with situations suggestive of fear or uncertainty, attachment needs are activated and will be met if there are accessible and receptive figures, conditions necessary for the construction of bonds (Johnson, 2012). Unlike the parent-child relationship, however, relationships between couples tend to involve partners in a less asymmetric way. Involvement with a new partner can be understood, in this scope, as requiring abilities to explore novelties, face fears and uncertainties, and endure hardships.

Two dimensions have been shown as adequate to explain adult attachment: anxiety and avoidance 
(Bartholomew, 1990; Bartholomew \& Horowitz, 1991). These dimensions relate to ways of responding to different situations that invoke feelings of fear or being threatened. They have first been described in terms of models of self (the self is worthy of love and support or not) and models of others (other people are trustworthy and available or unreliable and rejecting) (Bartholomew \& Horowitz, 1991). Highly anxious responses refer to attempts to seize the partner and impede distancing. They have shown relation to a negative model of self. Low anxiety, on the other hand, relates to a positive model of self. Highly avoidant responses, in turn, relate to avoiding affective closeness and difficulties in seeking or offering help. They were described in terms of negative models of others. Low avoidant responses, in turn, refer to positive models of others.

From the combination of anxiety and avoidance dimensions, Bartholomew \& Horowitz (1991) proposed four attachment styles: secure, preoccupied, dismissive and fearful. The secure style is characterized by low avoidance and low anxiety, which involves positive models of self and others. It showed relation with less interpersonal problems, positive self-concepts and good sociability (Bartholomew, 1990; Bartholomew \& Horowitz, 1991). They characterize the preoccupied style by low avoidance and high anxiety, involving positive models of others and negative models of self. It showed relation with good sociability and a tendency to behave in a controlling or dominating way in interpersonal relationships. Furthermore, people who present this style tend to interpret unpleasant social interaction as their own fault (Bartholomew, 1990; Bartholomew \& Horowitz, 1991). The authors described the dismissive style in terms of high avoidance and low anxiety. Dismissive individuals tend to be less sociable and to present cold, introverted and competitive behaviors in interpersonal relationships, being more prompt to interpret unpleasant social information by downplaying other peoples' importance and, therefore, maintaining a high self-esteem (Bartholomew, 1990; Bartholomew \& Horowitz, 1991). While the fearful style is characterized by high anxiety and high avoidance, involving negative models of self and others. It presented relation with social insecurity and lack of assertiveness, accompanied by the view of oneself as undeserving of love and support (Bartholomew, 1990; Bartholomew \& Horowitz, 1991). Although in clinical sampling the fearful style showed relation with violent relationships, especially in perpetration, in community samples it presented no relation and pointed to shy individuals (Henderson, Bartholomew, Trinke, \& Kwong, 2005). In sum, the label 'insecure style(s)' is used to refer to the three non-secure styles jointly (preoccupied, dismissive and fearful).

A large number of studies have examined the relationship between intimate partner violence and attachment. A recent systematic review identified 113 studies that investigated attachment as a predictor of victimization or perpetration of intimate partner violence (Velotti, Zobel, Rogier, \& Tambelli, 2018). Even though some heterogeneity was found in samples, measure instruments and inconsistency in the results regarding the kinds of violence (generic, psychological, sexual and physical), in general, findings support the hypothesis of a relation between insecure attachment and being victim or perpetrator of violence against the partner. Specifically, there is evidence that preoccupied attached individuals presented a higher tendency to stay in violent relationship dynamics, to tolerate abuse and to interpret it as closeness and intimacy (Henderson et al., 2005), besides showing higher difficulty to interrupt emotional bonding even after separation (Henderson, Bartholomew, \& Dutton, 1997). Other studies have indicated an association between dating violence perpetration and greater attachment anxiety and lower attachment avoidance (Tussey, Tyler, \& Simon, 2018), as well as an association between dating violence victimization and the preoccupied attachment style (McClure \& Parmenter, 2017). Moreover, some studies have pointed that all insecure attachment styles showed association with experiencing violent relationships, be it as victim or perpetrator (Bonache, Gonzalez-Mendez, \& Krahé, 2016, 2017). Besides, resorting to violence is more likely in conflict resolution when both partners present insecure attachment styles (Bonache et al., 2016, 2017), especially if one of them is dismissive and the other preoccupied (Schachner, Shaver, Mikulincer, 2012). Such evidences, derived from international quantitative studies, are in accordance with qualitative findings in samples composed of Brazilian youths (Murta et al., 2019).

\section{Our study}

Although few studies have begun to explore the trajectories of multiple violent relationships, including some risk and protection factors, we found no study that investigated the transition process or explored aspects that favor moving to a new violent relationship or to a healthy one. Thus, a better understanding of the relationship transition has the potential to offer understanding and tools to enable advancing the prevention and treatment of violence in romantic relationships. With this in mind, the focus of this study is to understand the transition to a new healthy or violent romantic relationship after the break-up of a violent one, as well as the aspects that favor or impair such an outcome, based on the theoretical lens of the Transtheoretical Model of Change and Attachment Theory.

This study aims to advance the findings of previous studies (Anderson, 2003; Bell et al., 2007; Burke et al., 2001; Murta et al., 2014) through the investigation of the characteristics of the transition to new relationships that favor overcoming violence by entering a new healthy relationship versus endangering this outcome by entering another violent relationship after ending a violent one. 


\section{Method}

\section{Participants}

We used a multiple case study (Yin, 2010) design, as this study was part of a broader effort that analized the ending process as well as the transition to new relationships. Since this is one of the first studies to examine the transition to new healthy relationships, we considered the case study the best design to explore the topic in depth. We recruited the participants through the snowball method. Emails and cell phone app messages were sent describing the profile of interest: people who had ended a violent romantic relationship. A relationship was considered romantic if the participant identified it as such. Seventeen people responded with interest and seven people - six women and one man - were interviewed. Among participants, five had had more than one violent relationship. To address the transition process, the object of this article, we selected two cases: one female participant who had been in a violent relationship and, at the time of the research, was in a healthy relationship, and another female participant who had been in two violent relationships and ended the last one about one month before taking part in the study. We selected them based on the similarity of social demographic characteristics (as summarized in Table 1) and circumstances of the first relationship analyzed: they both began when participants were adolescents, they were their first romantic relationships and included similar forms and dynamics of violence. Psychological violence was predominant and included controlling and restraining choices - of clothes, friendships, places and activities in which they could engage -, demanding submission to the partner's will and opinions, ignoring one's feelings, constantly insulting and depreciating their characteristics,

Table 1. Socio-demographic data of the participants

\begin{tabular}{lcc}
\hline Characteristics & Case 1 & Case 2 \\
\hline Name & Marília & Isabel \\
Age & 23 & 22 \\
Sex & Female & Female \\
Race & White & White \\
Sexual orientation & Bisexual & Heterosexual \\
Social Class* & C & C \\
Income (R $\$$ month) & $3,000.00$ & None \\
Occupation & Student & Student \\
$\begin{array}{l}\text { Education } \\
\text { \# of violent relationships }\end{array}$ & Some college & Some college \\
$\begin{array}{l}\text { Ages when lived } \\
\text { violent relationships }\end{array}$ & 17-18 and 20-23 & 1 \\
Time since the end of the & 1 month & 3 years \\
last violent relationship & & \\
*: social class of the family of origin according to the Brazilian Institute \\
of Geography and Statistics.
\end{tabular}

dreams, goals, tastes, and skills. The dynamics which favored violence perpetration included breaking up when not obeyed (which led to constant break ups and resumes), attributing guilt to participants for the relationship's problems, restrictions of social interactions and a cycle of diminished self-esteem related to the violence. We used pseudonyms in place of the actual names of participants and their partners.

\section{Procedures and instruments}

This study combined different sources of evidence, as recommended in the case study design (Yin, 2010). We used two instruments: the Brazilian version of the Experiences in Close Relationships (ECR) scale (Shiramizu, Natividade, \& Lopes, 2013), originally developed by Brennan, Clark and Shaver (1997), and a semi-structured interview script based on the narrative interview technique (Jovchelovitch \& Bauer, 2000). The ECR, based on the attachment theory, contains 36 statements, distributed in two factors that measure anxiety (for example: "Sometimes, my desire to be so affectively close ends up scaring people".) and avoidance (for example: "I worry when my partner gets too affectively close to me".) in intimate relationships. It uses a 7-point Likert scale, ranging from "disagree completely" to "agree completely" and it presented an alpha coefficient of 0.91 for the anxiety dimension, and of 0.89 for avoidance.

The narrative interview consists of five stages: preparation, initiation, main narration, questioning, and conclusion (Jovchelovitch \& Bauer, 2000). The preparation phase, which took place before the actual interview, consisted of prolonged contact with the field to be investigated. At this time, exmanent questions were developed - those of interest to the researcher - and these were then transformed in immanent questions themes and topics to be explored during the narration (Jovchelovitch \& Bauer, 2000). One example of exmanent question in this study addresses the characteristics of transition between romantic relationships that favor entering a healthy relationship. Rather than pose this question directly, the exmanent question is transformed into an immanent question, with the goal of obtaining a less-processed narration of the facts. In reality, this required a number of questions, such as: "Could you tell me a story that characterizes the period you went through after ending your relationship with [partner name]"?; "Tell me, what was the period when you met [partner name] like"?; "Give me an example of something you both experienced at the beginning of the relationship that made you see that this relationship was different from the previous ones". The preparation phase took place within a psychosocial advisory service that assists couples and ex-couples involved in domestic violence against women, in which the first author of this study was participating as an advisor. 
During the initiation phase, the proper beginning of the interview, we presented the context of the investigation to the participant and explained the narrative interview procedure (Jovchelovitch \& Bauer, 2000). After clarifications about this study's focus, we invited the participants to make a timeline of all the dates or other types of significant intimate relationships they have had. Next, we asked them to summarize the history of these relationships and, from there, identify in which relationship(s) they experienced violence. After this, together with the participants, we selected a piece of history that included a first violent relationship and the transition to a second significant relationship, whether healthy or violent. This piece could include other brief relationships or ones with a lesser degree of commitment in the interim.

In the next phase, the main narration, we requested the participants to tell the story of the first relationship, of the intermediate period, and of the second relationship, thereby building a new timeline from the selected segment. At this time, there were no interruptions, and the interviewer encouraged talking using non-verbal signs (Jovchelovitch \& Bauer, 2000).

The posterior phase, the questioning phase, began when the participants concluded their spontaneous narrative. The semi-structured interview script was built to allow the interviewer to note points that had already been addressed. For those that had not yet been addressed, we added questions to stimulate narration of specific situations or periods. This phase included questions to identify the moment of entry into each stage of change if such was not clear in the narration, and to describe the actively used strategies or the characteristics of violence in the relationship.

Finally, in the concluding phase, we applied the ECR (Shiramizu et al., 2013). Although the scale application instructions require taking into consideration all the relationships the person has had in general, in this study, to explore the connections between attachment and transition to new relationships after experiencing a violent one, we requested that the participants filled out two copies of the ECR: one that took into account the period when the first relationship (violent) narrated happened and the second for the period when the second relationship took place (violent or healthy).

By the end of the interview, in addition to the care taken for the participants' well-being, as described in the ethical considerations section, we asked them to contact the researcher if they remembered anything that would complement their narratives. 'Marília' was the only one to do this, forwarding a copy of some journal pages she had written at the end of the first violent relationship, whose contents described how she felt after its end. We contrasted this data to that collected in the interview, functioning as an analysis validation strategy. We conducted the interviews in the offices of a community center at the University of Brasília.

\section{Data analysis}

We performed data analysis in five stages as shown in Figure 1. In the first stage, a free reading of the transcribed material - that included taking notes on analysis possibilities - was done for greater familiarity with the reports. In the second stage, we identified excerpts from the reports covering the process of relationship construction, ending, and transition. The third stage consisted of identifying categories inside each of these processes. The construction process constituted a single category, without subcategories. We subdivided the ending process according to the stages of the transtheoretical model of change: precontemplation, contemplation, preparation, action, and maintenance (Prochaska et al., 1992; Shorey, Tirone, Nathanson, Handsel, \& Rhatigan, 2013). The data related to the ending process will be thoroughly analyzed in another article. The transition process comprised four subcategories that emerged as themes from the previous stage analysis: (1) strategies adopted in the period between relationships to avoid going back to the old relationship or beginning new violent ones; (2) characteristics of the relationships between the two main narrated relationships; (3) contextual aspects of the transition period, and (4) outcomes in the form of engaging in relationships. In the fourth stage, the construction of a relationship timeline and intra-case analysis was done. To maintain the connection between individual stories - as is typical in case studies - instead of considering the interviews within defined categories, we built timelines of each participant's relationships, including all the reported relationships, the violent experiences, and the transtheoretical model stages. We arranged these events chronologically, giving the opportunity to analyze the links related to each case. We addressed the processes of constructing and ending violent relationships and transitioning to new ones in the timeline. The last stage of qualitative data analysis included a comparison between cases - the individual processes of ending a violent relationship as well as transitioning to a new one - and the identification of similarities and differences. Figure 1 summarizes the process of data analysis.

To analyze the ECR data, the percentiles for the Brazilian population of the reduced version of the scale, we used psychometrically equivalent to the extended version (Shiramizu et al., 2013) (Natividade \& Shiramizu, 2015), as the extended version's data was unavailable. The social-demographic characteristics of this study's participants are in accordance with those predominant in the sample of Natividade and Shiramizu (2015). The anxiety and avoidance dimensions were plotted in a cartesian plane and their crossing indicates the $50^{\text {th }}$ percentile for the female population according to the distribution found by the authors. The point that links the two dimensions was indicated for each of the participants in the two periods for which narrations had been requested: that of the first relationship (violent) and that of the second (violent or otherwise). 


\begin{tabular}{|c|c|c|}
\hline \multicolumn{3}{|c|}{$1^{\text {st }}$ stage: familiarization with the data } \\
\hline \multicolumn{3}{|c|}{$2^{\text {nd }}$ stage: delimitation of processes } \\
\hline Construction Process & Ending Process & Transition Process \\
\hline \multicolumn{3}{|c|}{$3^{\text {rd }}$ stage: definition of categories within each process } \\
\hline Construction Process & Ending Process & Transition Process \\
\hline \multirow{4}{*}{ Single Category } & - Pre-contemplation & - Adopted strategies \\
\hline & - Contemplation & - Characteristics of context \\
\hline & $\begin{array}{l}\text { - Preparation } \\
\text { - Action }\end{array}$ & $\begin{array}{l}\text { - Charcateristics of intermediate } \\
\text { relationships }\end{array}$ \\
\hline & - Maintenance & - Outcomes related to engaging \\
\hline \multicolumn{3}{|c|}{$4^{\text {th }}$ stage: construction of relationship timeline and intra-case analysis } \\
\hline \multicolumn{3}{|c|}{$5^{\text {th }}$ stage: comparison between cases } \\
\hline
\end{tabular}

Figure 1. Stages of data analysis

After the analysis process, we presented the results to each participant in order to validate the researcher's analysis and check the information. They made only minor adjustments in terms of periods of facts. Both participants considered that interpretation of data was consistent with their experiences and that it also brought good insight.

\section{Ethical considerations}

This study was approved by the Committee for Ethics in Research of the University of Brasilia (protocol: 57966016.0.0000.5558). Beyond the guarantees granted in Resolution CNS 466/12 ("Resolução CNS", 2012), which presents guidelines and norms for research with human beings in Brazil, duly presented in the terms of informed consent, information about public and private networks of assistance was made available, based on demand shown by the participants. An additional meeting was offered to resolve any possible emotional discomfort that might have been caused by the research process. Moreover, as this is a case study and aimed to preserve anonymity, we omitted specific facts involving the subjects or described them in general terms in the presented results. This was particularly crucial given that an ex-partner shared the same information and, therefore, not taking extra precautions would have been risky. Furthermore, we promised the participants that, should any possible risks due to the participation in the research be identified, it would be suspended and a risk assessment, analysis of protective alternatives, and referral to appropriate services in conjunction with the researcher would be done. However, this was not necessary in either of the cases.

\section{Results}

\section{Case 1: 'Marilia'}

Figure 2 presents Marília's relationship timeline. She had been in two violent relationships. The first one, with 'Carlos,' lasted one year and three months. They were both 17 years old when it began. In this relationship, violence began very early, around the first month, and consisted of restricting access to her friends and controlling her relationships with others, the places she visited, and forms of leisure she was allowed; of daily invalidation of her personal tastes, activities, and sources of joy; of threatening to end the relationship when his demands were not met; and hostile shouting and insistent accusations during fights. These only ceased once she gave in to him. She points out how her great emotional involvement with him made it difficult to perceive the violence.

The relationship with 'Daniel' lasted three years and began when she was 20 . He was ten years older than her. The violence began in the first months and encompassed the forms experienced with Carlos and four more: manipulation (using her sympathies to convince her to do something he wanted, but which harmed her or restricted her choices), gaslighting (causing her to doubt herself or discredit her own perceptions), creating a relationship of dependence on care for her health (in a dynamic where fights between the two descended into depressive crises and he then cared for her, bringing her out of the crisis), and provoking guilt so she would stay in the relationship and would be lenient about the violence. Unlike her relationship with Carlos, with Daniel the forms of aggression were quite subtle and veiled, making it difficult to identify them, which explains why she stayed in the pre-contemplation stage for so long. Furthermore, despite perceiving a few similarities between the two relationships since the beginning, she was highly emotionally involved with Daniel and would not credit these perceptions.

The break up with Daniel happened about two months before her participation in the study. Between those two relationships, she had had two others she considered significant that were not violent: she dated 'Lucas' for about five months and was with 'Juliana,' in an uncommitted relationship, for a similar period of time.

Upon breaking up with Carlos, she leapt from precontemplation to action (with the ending of the relationship as reference) without going through the intermediate stages. She only realized the relationship had been violent some time after ending it. Thus, she did not go through the periods of contemplation and preparation. She made the decision to stay out of the relationship because the suffering was too high. Hence, she identified her suffering in the relationship, but did not attribute it to the violence, interpreting it instead as her own incapacity to attain his requirements: she only knew she could not bear the suffering anymore. 


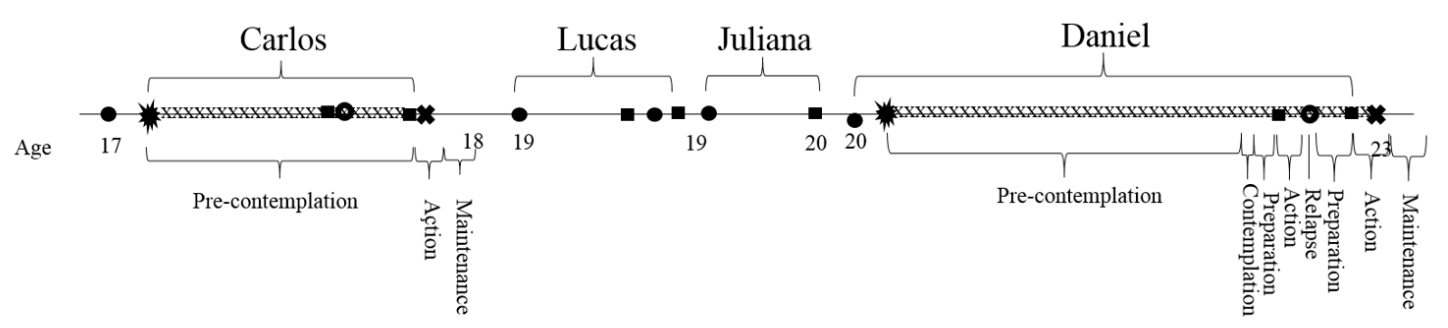

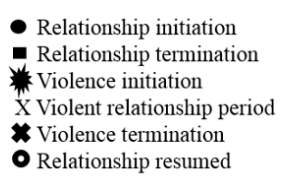

Figure 2. Marília's relationship timeline

Between the two relationships, she actively adopted strategies to avoid going back to Carlos and getting involved again in new violent relationships. These strategies included seeking social support, looking for new experiences, therapy, forms of self-care as well as identifying and reflecting on the problems of the first relationship, talking to new partners about them and trying to avoid pattern repetition. The contextual changes were entering college - where she encountered a greater variety of relationship models and new ideas - and broadening her worldview through new experiences and leisure options - such as traveling, frequenting places forbidden by her ex-partner, and adopting new aesthetics and style. Also, she got a car, which increased her autonomy.

The relationships in between Carlos and Daniel were not violent and had an important characteristic: her difficulty in identifying what she really wanted and how she really felt. This is seen in her getting back together with Lucas only because she felt lonely and in postponing breaking up with Juliana - because she could not understand how she felt about her - even if she frequently questioned herself about continuing the relationship. Both relationships ended because she did not feel involved with the partners anymore. The outcomes of how she romantically involved herself had to do with seeking more freedom in the relationship, by having an open relationship with Daniel, which was, nonetheless, violent.

Marília answered the ECR the same way for both periods that included the relationships, in other words, there were no changes in the responses to the instrument's items. Thus, both periods presented the same score in the avoidance and anxiety dimensions, as shown in Figure 3. She presented high anxiety (70th percentile) and high avoidance (80th percentile). These characteristics are typical of the fearful-avoidant attachment style, which is associated with dissatisfaction in romantic relationships, a tendency to submit and higher chances of involvement in violent relationships.

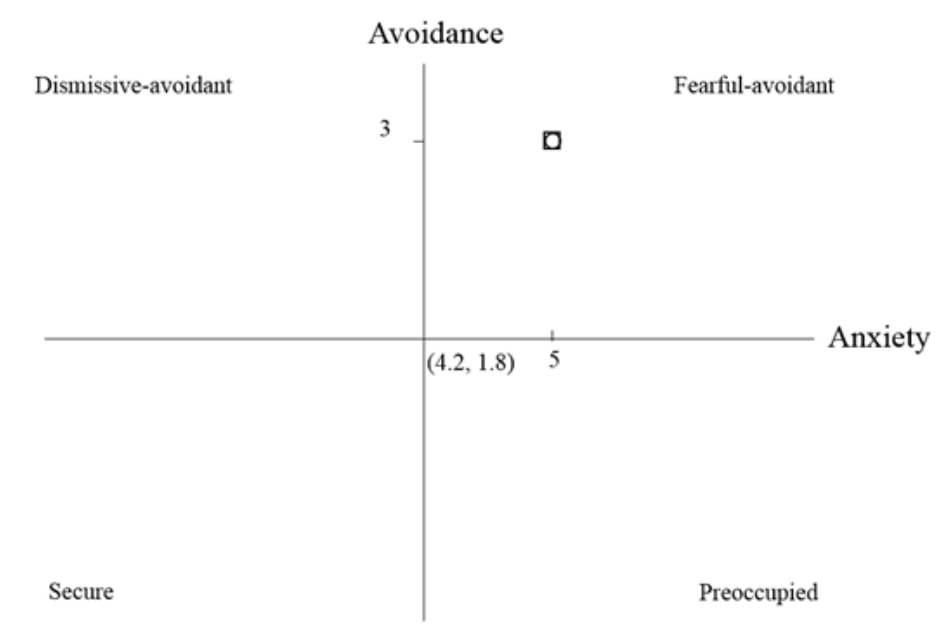

\footnotetext{
Attachment dimensions at the time of first violent relationship. $\square$ Attachment dimensions at the time of second (current) relationship.
}

Figure 3. Dimensions of avoidance and anxiety during both of Marilia's relationships 


\section{Case 2: 'Isabel'}

Figure 4 presents Isabel's relationship timeline. She had a violent relationship with 'Ricardo' that lasted four years. When the relationship began, she was 15 and he was 21 years old. Violence was present almost from the beginning of the relationship and consisted mainly in the persistent control of her friendships, places she frequented, and her conduct; in the hostile shouting when something was not to his liking; in breaking up with her every time she refused to submit to him, and in the disqualification of her decisions. Further into the relationship, there was an episode of physical violence and damage to property, in which he squeezed her wrists to the point of leaving bruises. At the beginning of the relationship, she evaluates she was in love with Ricardo and, although suffering greatly, she did not consider the possibility of breaking up. It took more than one attempt to break up with him. In the first try, she jumped from contemplation to action. Then there was a relapse to the preparation stage (she returned to the relationship). More consistent preparation brought her greater success in the second attempt to end it, which was definitive. At the time of data collection, Isabel had been in a healthy relationship with high level of satisfaction for a year. The relationship with 'Fernando' includes mutual support and care, respect for individuality and each other's limits, sexual affinity, dialogue and a high degree of negotiation with respect to opinions and feelings. We found no indication of violence in her report. Between the two primary relationships she had two shorter, non-violent, uncommitted relationships she considered important: 'Júlio,' which lasted about six months, and 'Murilo,' for approximately three months.

In the transition between the violent relationship and the healthy one, Isabel actively adopted strategies to keep her from returning to the relationship as well as to avoid entering a similar one. She strengthened her friendships and developed social groups for greater leisure possibilities (something she had already started doing in the preparation stage, since that had been an important barrier to the first break-up attempt). Additionally, she engaged herself in experiences that had been forbidden by Ricardo. This strategy brought changes as they enlarged her spheres of interaction, which in turn granted access to new ideas and relationship models. Other strategies she actively pursued included self-care, for example, yoga, meditation, and, about a year after breaking up, psychotherapy.

In both intermediate relationships, she broke up after noting important incompatibilities between her and her partners, despite having had strong feelings for them. In Júlio's case, she realized her expectations regarding the relationship's future were far above what he was willing to offer. As for Murilo's, they had had two fights (in which there was no violence, but they were stressful to both of them) and agreed that, if a new fight occurred, they would end the relationship, which they did effectively, despite liking each other. The outcomes from these strategies and her new experiences in the way she related to others were: an increased ability to identify and validate what she wants and feels and a decrease in the need to attend to other people's expectations at any cost. Because of her ability to better identify her own feelings, will, and perceptions and validate them, she boosted her skill to be assertive about respecting her own limits, space, and needs. Isabel identified this ability as the key element that allowed her to develop a healthy relationship, as from this arose positive characteristics of her relationship that concerned her.

Isabel presented a significant decrease in the avoidance dimension, $75^{\text {th }}$ percentile in the first relationship to $50^{\text {th }}$ in the second (which was current at the time of the study), nearly reaching the secure attachment style. She maintained a stable level of anxiety between the two periods $\left(50^{\text {th }}\right.$ percentile). Figure 5 presents the results of avoidance and anxiety in the two periods.

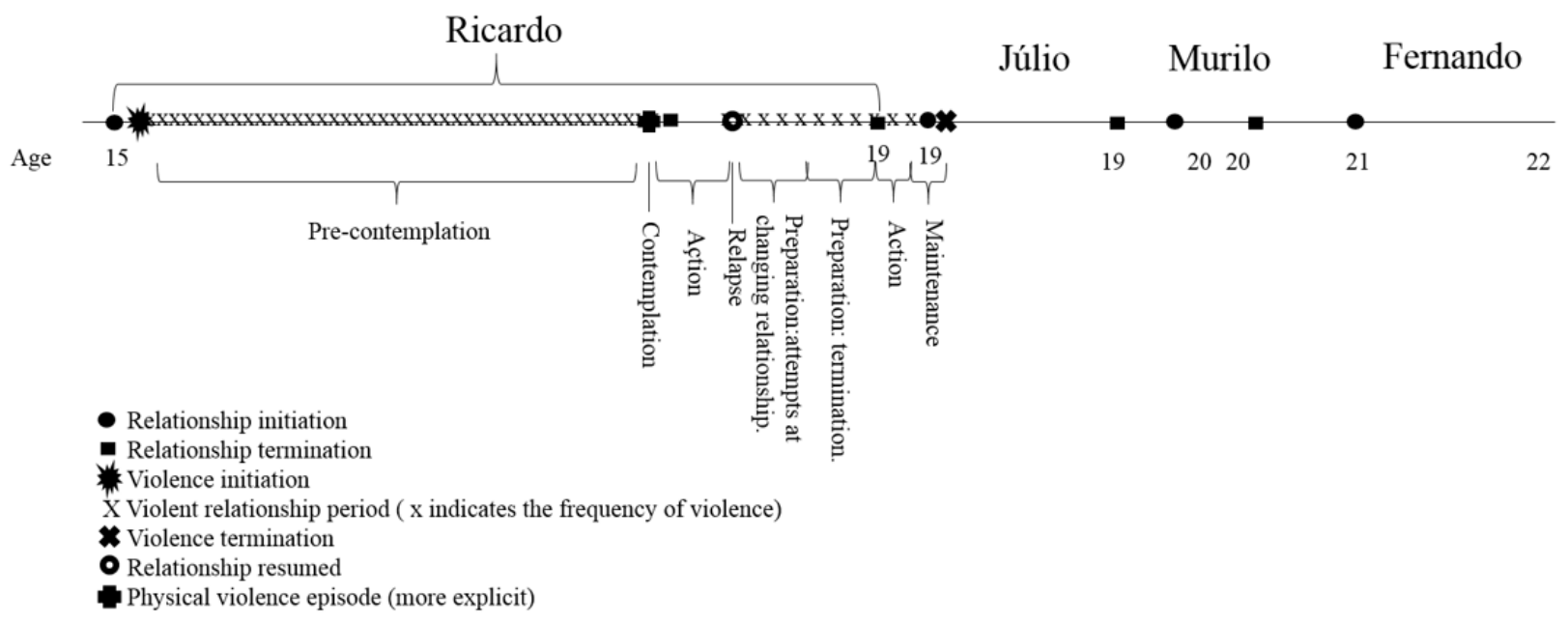

Figure 4. Isabel's relationship timeline 

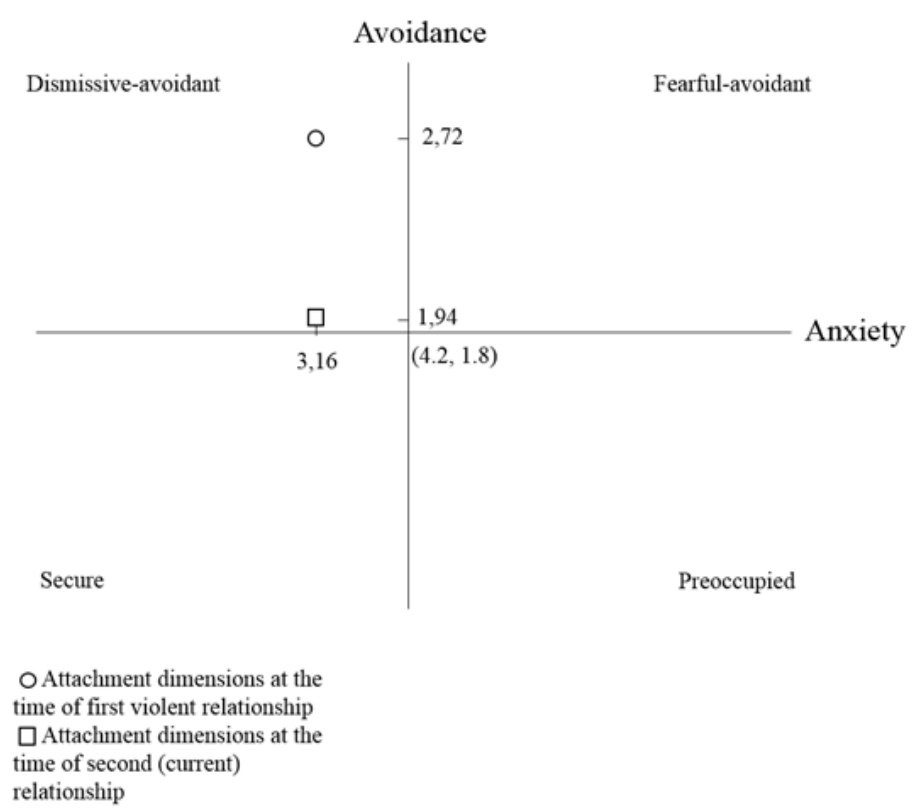

Figure 5. Dimensions of avoidance and anxiety during each of Isabel's relationships

\section{Case comparison}

In both cases presented, the participants actively resorted to several strategies when ending violent romantic relationships and moving to new ones. Both participants had social support and helpful relationships and sought out new experiences, broadening non-romantic relationships, and access to new ideas and worldviews. Moreover, both clearly identified violence in the relationship after its end and turned to psychotherapy and strategies of self-care. The contextual changes for both participants brought new relationship models and ideas, beyond broadening their social support. They evaluated these strategies positively in terms of the quality of life they brought and began when they were seeking to prevent themselves from returning to their partners from the first violent relationships: the maintenance stage.

The divergent aspects of relationship transition between the two participants lay mostly in the intermediate relationships and outcomes experienced in the new significant ones. Neither of them experienced violence in the intermediate relationships. There were, however, differences in these relationships' paths. Marília had difficulty in making the decision to break up, thus prolonging or getting back to them because she felt lonely or found it hard to understand what she felt for the other person. Isabel, on the other hand, managed to end them once she noted important incompatibilities, even when strong feelings for the other person persisted.

As an outcome of how she engages in relationships, Isabel experienced gains in her ability to allow herself to validate what she feels and wants in concrete situations in a relationship. This decreased her attempts to attend other's expectations at any cost. By allowing herself to want, perceive, and validate what she felt, thought, and desired, she began to be more assertive in relationships regarding her space, her will, and respect for her limits, reciprocally respecting these aspects about her partner. Marília, in turn, reported that the main outcome of how she engages in a relationship had been perceiving her need for freedom in them, which ultimately led to her decision to have an open relationship. Such an outcome, nevertheless, did not impede her from suffering restrictions to freedom and attempts to control her in the new violent relationship.

\section{Discussion}

This study investigated how the transition to a new relationship after the break-up of a violent one takes place and which dimensions favor or impede overcoming that violence in new relationships. The results suggest there are diverse transition paths with heterogeneous outcomes leading either to a new violent relationship (Marília) or to one that is healthy and highly satisfactory (Isabel).

The strategies associated with perceiving problems in the violent relationship, observing the new partner's characteristics, and talking to the new partner about the previous relationship's undesirable aspects did not promote, at least by themselves, the transition to a healthy relationship. Broadening and strengthening friendships and diversifying experiences - strategies involving greater social support, access to new relationship models, and contact with other ways of thinking about relationships - did not favor the transition either. On the other hand, these strategies have been shown to be valuable in previous studies (Anderson, 2003; Murta et al., 2014). In other words, although such strategies favor exiting a violent relationship, they do not seem to protect against entering a new one, even if the onset of aggression happens in the first few months. 
Thus, the mere perception, labeling, and awareness of violence did not prove to be enough for avoiding a new violent relationship. On the other hand, skills that associated with accessing and validating one's own feelings and desires have been shown to be necessary. This process of greater self-perception - feelings and desires - led to outcomes of increased assertiveness in the new relationship and lessened anxiety about attending other peoples' demands. However, communication skills concerning assertiveness were not as important as the processes which happened prior to communication: accessing how one feels about something in order to understand what is actually wanted and then validate this perception for oneself. In other words, giving oneself the right or entitlement to do so. According to the attachment theory, this ability to understand what one wants seems close to what defines self-confidence, as emphasized by Bowlby (1998) as the result of wellestablished attachment relationships, in the sense of perceiving oneself as being worthy of value.

In terms of attachment, we can identify some characteristics in both of the participants' narratives. Typical behaviors of preoccupied style can be observed when Marília ends her first relationship, as she clearly considered herself inferior to her partner and believed the cause of the problems she had experienced were due to her lack of capacity to attain his level. Besides, her recurrent resume of intermediary relationships also suggests a preoccupied style dynamic: the need to have a partner, instead of the way she felt about them, confuses her and drives decisions. Isabel, by her turn, could not even consider breaking up at the beginning of the first (and violent) relationship despite her great suffering, which is also characteristic of preoccupied attachment. On the other hand, she was able to do so in her intermediary relationships once she realized the partners could not correspond to her expectations and needs even having strong feelings for both. When doing this, she did not attempt to diminish their value or qualities, neither hers, which suggests she keeps positive models of herself and of others, typical of secure attachment. The same is observed about her perceived decrease in the need to attend the partner's expectations and demands at any cost - one of the changes she points as essential for the positive outcomes she had -, which suggests reduction in the anxiety dimension level. In turn, Marília's most significant change - the decision to have an open relationship to feel more free - can be interpreted as an avoidant behavior. Such a conclusion, though, would merit more studies. Previous research found relation between the avoidant style and having multiple partners in shortterm mating, especially for men (Schmitt \& Jonason, 2015). Nevertheless, an open relationship includes an important bond with one partner and the possibility to have other occasional partners, which is something a preoccupied person would probably not bear.

Regarding the ECR results, Isabel, who transitioned to her current healthy relationship, showed a considerable reduction in avoidance compared to when she had been in a violent relationship, thereby nearing secure attachment style. Marília, in turn, who transitioned to a new violent relationship, did not present differences in anxiety and avoidance between the two relationships. Therefore, it is necessary to analyze what these outcomes are associated with, which we present as follows.

The changes in attachment presented by Isabel merit analysis. The changes highlighted in her narrative are typical of a transition from preoccupied to secure style: the decrease in the need to attend to the partner's expectations or to be in a relationship at any cost - which, in her narration, she associated with the ability to access and validate her own feelings and desires. She did not, however, present reduction in anxiety, but in avoidance. Still, Isabel's movement towards secure attachment was evident. Bartholomew and Horowitz (1991), in the study that first pointed to the four category attachment styles model, noted that a large part of the participants presented characteristics belonging to more than one attachment style and that such individual specificities were camouflaged when working with collective data. Bonache et. al (2016) indicated that the dismissive style - in the face of a partner's demands - may resort to behaviors of super-engagement, a typical preoccupied attachment strategy. These results indicate that, within certain circumstances and more especially in the case of insecure styles, anxious and avoidant responses can occur regardless of a person's dominant attachment style. Moreover, when dealing with individual cases, considering insecurity in general can be useful.

Regarding the characteristics of the intermediate relationships, these seem to have functioned as a thermometer for the aspects that promoted the transition to a healthy relationship: the ability to end relationships because of incompatibilities even when feelings for the partner still existed preceded entering a healthy relationship. In this sense, the validation of perceptions, feelings, and will - shown here as promoting healthy relationships seems to be indicative of a positive transition as well: if this process does not occur satisfactorily, returning to or prolonging relationships that do not bring happiness or do not attend the person's needs is more likely, as it occurred with Marília. On the other hand, the ability to end a relationship once aware of incompatibilities and despite having feelings for the other person seems to be an indicator of advances in this process.

Thus, we can observe in the results of this study that there are two aspects moving together and pointing to changes that favor the construction of healthy relationships: approximating the secure attachment style and the ability to validate feelings, perceptions, and desires and then communicating these to the partner assertively. Future research will be able to study the relationship between these two elements more deeply.

Attention must be addressed to gender issues identified in both women's narratives. Firstly, both dated 
at any point men who were considerably older than them. Isabel was 15 when she started dating Ricardo, while he was 21. Although this six-year difference would not be high in other phases of life, it implied, for them, different phases of development, with him being a young adult and she, an adolescent. As for Marília, she was 21 (a young adult) when she began dating Daniel (her second violent relationship), who was 31 (an adult). Although dating much younger partners is not exclusive to men, they apparently do this more frequently. It deserves attention as differences of age can convert in differences of power in the relationship as it allows the older partner, who has more experience, to easily dominate and control the younger one. Also, it should be pointed that although neither of the participants presented preoccupied attachment, they both showed, at some point, characteristic behaviors of this style, especially those related to the need to have a partner. It should be noted that this style is more frequent in women (Natividade \& Shiramizu, 2015; Shiramizu et al., 2013). This brings into question that some experiences, like the difficulty of leaving a partner despite of bad relationship quality and the centrality of romantic love, besides being a characteristic that points to high anxiety in attachment, also indicate a lot about women's socialization in terms of how they are supposed to perform in relationships: the centrality of being chosen by a man, and seeing themselves as responsible for the relationship and its quality (Zanello, 2018). Reinforcing this possible interpretation is the fact that we observed no other characteristic of preoccupied attachment (e.g. the need to have great closeness and intimacy) in any of the participants. This could also explain, for example, why the partners frequently ending (and later resuming) the relationship was so devastating to them even in face of absurd demands: they were confronted at the same time with insecurity in attachment and with social structures and prescriptions for women - which transcends individual characteristics.

The results indicate the complexity of the processes needed to overcome and prevent relationship violence. For prevention, especially universally applicable (that is, directed at the entire population), the first and most obvious strategy is fostering the quality of early family relationships which reduces the risk of child mistreatment, interparental violence, and witnessing violence between parents, which in turn prevents acceptance of violence, victimization (Karlsson, Temple, \& Weston, 2015), and perpetration of dating violence (Barbaro \& Shackelford, 2019). Initiatives which insert mental health and the promotion of safe attachment into basic health care and, more specifically, in the following of gestating families show great preventive potential, as predicted in the National Policies for Integral Child Health Attention (Ministério da Saúde, 2018).

The effect of other attachment styles must be considered as well. Attachment characteristics are molded in the first years of life, with a strong influence from parental relationship quality, and, while not immutable, they tend to be relatively stable (Bowlby, 1998; Scharfe, 2012). Other relationships established over the course of one's development can, however, promote changes in attachment style if they promote accessibility, receptiveness, and stimulus to autonomy. Teachers, extended family, siblings, friends, and romantic partners, for example, can be important figures in propitiating changes in attachment. Following this, investments in the performance of the protective role of professionals who work with children and adolescents may bear fruit from the point-of-view of universal prevention. Moreover, initiatives promoting community relationships with greater accessibility and mutual trust tend to provide a larger number of secure relationships and decrease the number of situations that activate insecure attachment systems.

For selective prevention (directed at a risk group), insecure attachment has shown to be a risk factor. In this case, especially for adolescents and young adults, interventions focused on the promotion of responsiveness and security in affective bonds are recommended. Previous studies have indicated that the activation of secure attachment through the use of images or suggestion, regardless of attachment style, tend to raise the number of responses that are more empathetic and less aggressive toward external groups (even in the context of an armed conflict, for example between Israel and Palestine) and more self-transcendent values (Mikulincer \& Shaver, 2001; Mikulincer et al., 2001). The viability of application to long-term impact interventions still demands more study. Investing in the quality of friendships as a source of accessibility and availability may prove a promising path as less instability and greater welcoming and support tend to generate more attachment responses. For adolescents presenting highly insecure attachment accompanied by mental health impacts, psychotherapy based on attachment restoration, a technique that employs the participation of family members, also seems promising (Diamond, Russon, \& Levy, 2016).

Likewise, improving social skills is a possibility to be explored in the prevention of violent relationships. The last outcome indicated for fostering the establishment of a healthy relationship was greater assertiveness. It is important to note, nevertheless, that the adoption of such a strategy must not be based on its communication aspects, but instead on its form in its initial stage: entitlement. The results of this study suggest that the difficulty with assertiveness in violent relationships resides not in the point of knowing how to communicate, but in a prior step: identifying what one wants to communicate. Overall, cognitive-affective aspects of this skill are important, that is, the security that one's own feelings and desires are valid and worthy of respect and being attended. Thus, the central problem that must be addressed does not reside in the inability to properly say something, instead it lies in the lack of awareness of what one wants to communicate. These intervention strategies - based on promoting secure attachment and the ability to access and validate one's own perceptions, feelings, 
and desires - are necessary in the context of treatment as well, when there is already a considerable history of having experienced violent relationships.

This study's limitations are noteworthy. Firstly, it is impossible to generalize the data. As it was based in case studies, the data presented allows understanding a process, but limits its external validity to populational groups. Furthermore, the sample was composed of welleducated white participants narrating their relationship with people of the opposite sex (despite one of them being bisexual), who, even if not members of higher income classes, were not part of a vulnerable group either. Other social vulnerabilities associated with their dating violence history were not verified, which could lead to peculiarities in the studied processes. Secondly, the information about confronting violence and the transition to new relationships were both evaluated in retrospect, which brings limitations connected to memory. Finally, the lack of access to the partners or other informants is an important limitation.
Given ethical and practical specificities that hamper access to the partners, recruiting in environments where the couple is already being seen due to violence - for instance, in judicial spaces or places for assistance with violence - could be a viable alternative in future studies.

The influence of belonging to racial or sexual minorities deserves more attention in future studies about the transition to healthy relationships, especially considering the restriction of social support faced by these groups as a consequence of prejudice and discrimination. Despite including a bisexual participant, the primary relationships she reported had been with the opposite gender, limiting the analysis to people of the same gender. Finally, we recommend longitudinal studies, which can accompany the developmental trajectories of youths who abandon violent relationships and enter new ones, in order to deepen and expand the evidence of predictors of overcoming violence or revictimization by violence in intimate relationships.

\section{Transição para novas relações após o término de namoros violentos em mulheres brasileiras: um estudo de caso}

Resumo: Este estudo investigou características da transição para novos relacionamentos após o término de namoro violento por meio de estudo de caso. Duas mulheres brasileiras, jovens, brancas, com experiência de primeiro namoro violento, tendo uma delas transitado para relacionamento saudável e outra para nova relação violenta, responderam à entrevista narrativa e ao Experiences in Close Relationships Inventory. A tomada de consciência da violência e a adoção de estratégias que ampliaram modelos, visões de mundo, círculos sociais, suporte e autocuidado não se mostraram suficientes para evitar a entrada em novo relacionamento violento. O desenvolvimento da habilidade de acessar e validar os próprios sentimentos e desejos, resultando em maior assertividade, favoreceu a transição para relação saudável. A aproximação do estilo de apego seguro acompanhou tais mudanças. Implicações para prática profissional e iniciativas preventivas são discutidas, assim como direcionamento de pesquisas futuras.

Palavras-chave: violência pelo parceiro íntimo, violência contra a mulher, prevenção, apego.

\section{Transition vers de nouvelles relations après l'achèvement des relations amoureuses violentes chez les femmes brésiliennes : une étude de cas}

Résumé : Cette étude a examiné les caractéristiques de la transition vers de nouvelles relations qui ont favorisée l'entrée dans des relations saines après l'achèvement d'une relation amoureuse violente par le biais d'une étude de cas. Deux femmes brésiliennes, jeunes, blanche, ayant l'expérience de relations amoureuses violentes, ont répondu à l'entretien narratif et au Experiences in Close Relationships Inventory (Inventaire des expériences de relations étroites). Tandis que l'une d'entre eux avait transitée vers une relation amoureuse saine, l'autre avait adhéré à une nouvelle relation violente. La prise de conscience de la violence et l'adoption des stratégies qui ont élargi les modèles, les visions du monde, les cercles sociaux, les relations de soutien et la protection personnels n'ont pas été suffisant pour empêcher l'entrée dans une nouvelle relation violente. D'autre part, le développement de la capacité d'accéder à ses sentiments et désirs puis les valider, en resultant en plus grande assertivité, a favorisé la transition vers une relation saine. L'approche du style d'attachement sécure a accompagné ces changements. Les implications pour la pratique professionnelle et les initiatives préventives sont discutées, ainsi que des perspectives de recherches futures.

Mots clés : violence de la part du partenaire intime, violence contre les femmes, prévention, attachement.

\section{Transición hacia nuevas relaciones después del término de noviazgos violentos de mujeres brasileñas: un estudio de caso}

Resumen: Este estudio investigó las características de la transición hacia nuevas relaciones que favorecieron el comienzo de relaciones saludables, luego del término de relaciones violentas, por medio de estudio de casos. Dos mujeres brasileñas, 
jóvenes, blancas, con experiencia del primer noviazgo violento, habiendo una de ellas transitado hacia un noviazgo sano y la otra hacia una nueva relación violenta, respondieron a la entrevista narrativa y al Experiences in Close Relationships Inventory. La toma de conciencia de la violencia y la adopción de estrategias que ampliaron modelos, visiones de mundo, círculos sociales, apoyo social y autocuidado no se mostraron suficientes para evitar comenzar una nueva relación violenta. Por otro lado, el desarrollo de la habilidad para acceder y validar los propios sentimientos y deseos, que resultó ser más asertiva, favoreció la transición hacia una relación saludable. La aproximación a una forma de apego segura acompañó tales cambios. Se discuten las implicaciones en la práctica profesional y las iniciativas preventivas, así como las perspectivas de investigaciones futuras.

Palabras clave: violencia por el compañero íntimo, violencia contra la mujer, prevención, apego.

\section{References}

Anderson, C. (2003). Evolving out of violence: an application of the transtheoretical model of behavioral change. Research and Theory for Nursing Practice, 17(3), 225-240.

Barbaro, N., \& Shackelford, T. K. (2019). Environmental unpredictability in childhood is associated with anxious romantic attachment and intimate partner violence perpetration. Journal of Interpersonal Violence, 34(2), 240-269. doi: 10.1177/0886260516640548

Bartholomew, K. (1990). Avoidance of intimacy: an attachment perspective. Journal of Social and Personal Relationships, 7, 147-178. doi: 10.1177/0265407590072001

Bartholomew, K. (1997). Adult attachment processes: individual and couple perspective. British Journal of Medical Psychology, 70, 249-263.

Bartholomew, K., \& Horowitz, L. M. (1991). Attachment styles among young adults: a test of a four-category model. Journal of Personality and Social Psychology, 61(2), 226-244.

Barufaldi, L. A., Souto, R. M. C. V., Correia, R. S. B., Montenegro, M. M. S., Pinto, I. V., Silva, M. M. A., \& Lima, C. M. (2017). Violência de gênero: comparação da mortalidade por agressão em mulheres com e sem notificação prévia de violência. Ciência \& Saúde Coletiva, 22(9), 2929-2938. doi: 10.1590/1413-81232017229.12712017

Bell, M. E., Goodman, L. A., \& Dutton, M. A. (2007). The dynamics of staying and leaving: implications for battered women's emotional well-being and experiences of violence at the end of a year. Journal of Family Violence, 22(6), 413-428. doi: 10.1007/s10896-007-9096-9

Bonache, H., Gonzalez-Mendez, R., \& Krahé, B. (2016). Adult attachment styles, destructive conflict resolution, and the experience of intimate partner violence. Journal of Interpersonal Violence, 34(2), 287-309. doi: $10.1177 / 0886260516640776$

Bonache, H., Gonzalez-Mendez, R., \& Krahé, B. (2017). Romantic attachment, conflict resolution styles, and teen dating violence victimization. Journal of Youth and Adolescence. doi: 10.1007/s10964-017-0635-2

Bowlby, J. (1998). Separação: angústia e raiva. São Paulo, SP: Martins Fontes.

Brennan, K. A., Clark, C. L., \& Shaver, P. R. (1997). Selfreport measurement of adult attachment: An integrative overview. In J. A. Simpson \& W. S. Rholes (Orgs.), Attachment theory and close relationships (pp. 46-76). New York: Guilford Press.

Brown, J. (1997). Working toward freedom from violence: the process of change in battered women. Violence Against Women, 3(1), 5-26.

Burke, J. G., Gielen, A. C., McDonnel, K. A., O’Campo, P., \& Maman, S. (2001). The process of ending abuse in intimate relationships: a qualitative exploration of the transtheoretical model. Violence Against Women, 7(10), 1144-1163. doi: 10.1177/10778010122183784

Carbonne-Lopez, K., Rennison, C. M., \& MacMillan, R. (2011). The transcendence of violence across relationships: new methods for understanding men's and women's experiences of intimate partner violence across the life course. Journal of Quantitative Criminology, 28, 319-346. doi: 10.1007/s10940-011-9143-9

Diamond, G., Russon, J., \& Levy, S. (2016). Attachment-based family therapy: a review of the empirical support. Family Process, 55(3), 595-610. doi: 10.1111/famp. 12241

Estrellado, A.F., \&Loh, J.(2019). To stay in or leave an abusive relationship: losses and gains experienced by battered Filipino women. Journal of Interpersonal Violence, 34(9), 1843-1863. doi: 10.1177/0886260516657912

George, C., Kaplan, N., \& Main, M. (1985). The Berkeley Adult Attachment Interview. Unpublished manuscript, University of California, Berkeley, United States.

Greenman, S. J., \& Matsuda, M. (2016). From early dating violence to adult intimate partner violence: Continuity and sources of resilience in adulthood. Criminal Behaviour and Mental Health, 26(4), 293-303. doi: 10.1002/cbm.2012

Hazan, C., \& Shaver, P. (1987). Romantic love conceptualized as an attachment process. Journal of Personality and Social Psychology, 52(3), 511-524. doi: 10.1037/0022-3514.52.3.511

Henderson, A. Z., Bartholomew, K., \& Dutton, D. G. (1997). He loves me; he loves me not: attachment and separation resolution of abused women. Journal of Family Violence, 12(2), 169-191.

Henderson, A. Z., Bartholomew, K., Trinke, S. J., \& Kwong, M. J. (2005). When loving means hurting: an exploration of attachment and intimate abuse in a community sample. Journal of Family Violence, 20(4), 219-230. doi: 10.1007/ s10896-005-5985-y 
Johnson, S. M. (1986). Bonds as bargains: relationship paradigms and their significance for marital therapy. Journal of Marital and Family Therapy, 12(3), 259-267. doi: 10.1111/j.1752-0606.1986.tb00652.x

Johnson, S. M. (2012). Introdução ao apego: um guia terapêutico para lidar com os vínculos primários e sua renovação. In S. M. Johnson \& V. E. Whiffen (Orgs.), Os processos do apego na terapia de casal e família (pp. 3-16). São Paulo, SP: Roca.

Jovchelovitch, S., \& Bauer, M. W. (2000). Entrevista narrativa. In M. W. Bauer \& G. Gaskell (Orgs.), Pesquisa qualitativa com texto, imagem e som: um manual prático (pp. 90-113). Petrópolis, RJ: Vozes.

Karlsson, M. E., Temple, J. R, \& Weston, R. (2015). Witnessing interparental violence and acceptance of dating violence as predictors for teen dating violence victimization. Violence Against Women, 22(5), 625-646. doi: 10.1177/1077801215605920

Keeling, J., Smith, D., \& Fisher, C. (2016). A qualitative study exploring midlife women's stages of change from domestic violence towards freedom. BMC Women's Health, 16, 13. https://doi.org/10.1186/s12905-016-0291-9

Martsolf, D. S., Draucker, C. B., Stephenson, P. L., Cook, C. B., \& Heckman, T. A. (2012). Patterns of dating violence across adolescence. Qualitative Health Research, 22(9), 1271-1283. doi: 10.1177/1049732312449388

McClure, M. M., \& Parmenter, M. (2017). Childhood trauma, trait anxiety, and anxious attachment as predictors of intimate partner violence in college student. Journal of Interpersonal Violence. doi: 10.1177/0886260517721894

Mikulincer, M., \& Shaver, P. R. (2001). Attachment theory and intergroup bias: evidence that priming the secure base schema attenuates negative reactions to outgroup. Journal of Personality and Social Psychology, 81(1), 97115. doi: 10.1037/0022-3514.81.1.97

Mikulincer, M., Gillath, O., Halevy, V., Avihou, N., Avidan, S., \& Eshkoli, N. (2001). Attachment theory and reactions to others' needs: evidence that activation of the sense of attachment security promotes empathic responses. Jornal of Personality and Social Psychology, 81(6), 1205-1224. doi: 10.1037//0022-3514.81.6.1205

Ministério da Saúde (2018). Política Nacional de Atenção Integral à Saúde da Criança: orientações para implementação. Brasília, DF: Ministério da Saúde.

Murta, S. G., Pires, M. R. P., Tavares, A. S., Cordeiro, M. A., Teixeira, E. G., \& Adorno, N. (2019). Intimidade e apego no namoro: implicações de estudos de caso para prevenção à violência. Contextos Clínicos, 12(1). doi: 10.4013/ctc.2019.121.09

Murta, S. G., Ramos, C. E. P. L., Cangussú, E. D. A., Tavares, T. N. G., \& Costa, M. S. F. (2014). Desenvolvimento de um website para prevenção à violência no namoro, abandono de relações íntimas abusivas e apoio aos pares. Contextos Clínicos, 7(2), 118-132. doi: 10.4013/ctc.2014.72.01

Natividade, J. C., \& Shiramizu, V. K. M. (2015). Uma medida de apego: versão brasileira da Experiences in
Close Relationship Scale - Reduzida (ECR-R-Brasil). Psicologia USP, 26(3), 484-494. doi: 10.1590/0103656420140086

Prochaska, J. O., DiClemente, C. C., \& Norcross, J. C. (1992). In search of how people change. Applications to addictive behaviors. American Psychologist, 47(9), 1102-1114.

Resolução CNS no 466, de 12 de dezembro de 2012 (2012). Aprova diretrizes e normas regulamentadoras de pesquisas envolvendo seres humanos. Brasília, DF: Conselho Nacional de Saúde. Retrieved from: http://bit.ly/32ukV4j

Rodrigues, N. C. P., O’Dwyer, G., Andrade, M. K. N., Flynn, M. B., Monteiro, D. L. M., \& Lino, V. T. S. (2017). The increase in domestic violence in Brazil from 20092014. Ciência \& Saúde Coletiva, 22(9), 2873-2880. doi: 10.1590/1413-81232017229.09902016

Schachner, D. A., Shaver, P. R., \& Mikulincer, M. (2012). Teoria do apego adulto, psicodinâmica e relações conjugais: uma visão geral. In S. M. Johnson \& V. E. Whiffen (Orgs.), Os processos do apego na terapia de casal e familia (pp. 17-39). São Paulo, SP: Roca.

Scharfe, E. (2012). Estabilidade e mudança das representações de apego: do berço à morte. In S. M. Johnson \& V. E. Whiffen (Orgs.), Os processos do apego na terapia de casal e família (pp. 61-80). São Paulo, SP: Roca.

Schmitt, D. P., \& Jonason, P. K. (2015). Attachment and sexual permissiveness: exploring differential associations across sexes, cultures, and facets of short-term mating. Journal of Cross-Cultural Psychology, 46(1), 119-133. doi: 10.1177/0022022114551052

Shiramizu, V. K. M., Natividade, J. C., \& Lopes, F. A. (2013). Evidências de validade do Experience in Close Relationships (ECR) Inventory para o Brasil. Estudos de Psicologia, 18(3), 457-465. doi: 10.1590/S1413294X2013000300006

Shorey, R. C., Tirone, V., Nathanson, A. M., Handsel, V. A., \& Rhatigan, D. L. (2013). A preliminary investigation of the influence of subjective norms and relationship commitment on stages of change in female intimatepartner violence victims. Journal of Interpersonal Violence, 28(3), 621-642. doi: 10.1177/0886260512455520

Tussey, B. E., Tyler, K. A., \& Simon, L. G. (2018, February 23). Poor parenting, attachment style, and dating violence perpetration among college students. Journal of Interpersonal Violence. doi: 10.1177/0886260518760017

Velotti, P., Zobel, S. B., Rogier, G., \& Tambelli, R. (2018, July 5). Exploring relationships: a systematic review on intimate partner violence and attachment. Frontiers in Psychology, 9. doi: 10.3389/fpsyg.2018.01166

Yin, R. K. (2010). Estudo de caso: planejamento e métodos. Porto Alegre, RS: Bookman.

Zanello, V. (2018). Saúde mental, gênero e dispositivos: cultura e processos de subjetivação. Curitiba, PR: Appris.

Received: $12 / 02 / 2019$

Approved: 12/28/2019 